\title{
Dos Poemas
}

\section{El mundo es pura geometría.}

el mundo es pura geometría reclamaba Euclídes

mientras trazaba desde un punto el círculo de la vida

pero apenas y alcanzaba a explicar un plano

cuando las múltiples aristas de la línea se expandían

el centro es toda profundidad sin fondo

y es la periferia el límite del vacío

aunque no existe más allá la nada

o aquello que llamamos tiempo

el círculo se está cerrando

escribió Borges en algún poema

pero yo creo que más que cerrar se abre

y cubre en su extensión lo eterno

no importan los reclamos de aquél

o cualquier otro griego

que tan sólo el diseño de un poema

de simétrica o asimétrica escritura

vale toda la dimensión del universo.

\section{El día es un anzuelo luminoso.}

El día es un anzuelo luminoso

El viento frío la marea que lo mece

Observo que el viento pasa

En las colas de tierra que levanta

Nombrar el día es no acabarlo

Su imagen es su doble ser

Su tránsito

Desde el oriente

Hasta el horizonte azur

Del occidente

El día es la luz

El alfa y el omega 